SCIENTIFIC REPORT

\title{
Optic nerve oxygen tension: the effects of timolol and dorzolamide
}

\author{
J F Kiilgaard, D B Pedersen, T Eysteinsson, M la Cour, K Bang, P K Jensen, E Stefánsson
}

Br J Ophthalmol 2004;88:276-279. doi: 10.1136/bjo.2003.021857

Background/aims: The authors have previously reported that carbonic anhydrase inhibitors such as acetazolamide and dorzolamide raise optic nerve oxygen tension $\left(\mathrm{ONPO}_{2}\right)$ in pigs. The purpose of the present study was to investigate whether timolol, which belongs to another group of glaucoma drugs called $\beta$ blockers, has a similar effect. In addition, the effect of dorzolamide and timolol in combination was studied.

Methods: Polarographic oxygen electrodes were placed transvitreally over the optic disc in anaesthetised pigs and $\mathrm{ONPO}_{2}$ was recorded continually. Drugs were administered intravenously either as $100 \mathrm{mg}$ timolol followed by $500 \mathrm{mg}$ dorzolamide $(n=5), 500 \mathrm{mg}$ dorzolamide followed by $100 \mathrm{mg}$ timolol $(\mathrm{n}=5)$, or $100 \mathrm{mg}$ timolol and $500 \mathrm{mg}$ dorzolamide given simultaneously $(n=5)$. Arterial blood pressure, blood gasses, and heart rate were recorded.

Results: $\mathrm{ONPO}_{2}$ was unaffected by administration of $100 \mathrm{mg}$ timolol as an intravenous injection $(n=5)$. Administration of $500 \mathrm{mg}$ dorzolamide by itself significantly increased $\mathrm{ONPO}_{2}$ from 2.96 (SD 0.62 ) $\mathrm{kPa}$ to 3.69 (SD $0.88) \mathrm{kPa}(n=4, p=0.035)$. The dorzolamide induced $\mathrm{ONPO}_{2}$ increase was not significantly different from the $\mathrm{ONPO}_{2}$ increases were seen when dorzolamide was administered simultaneous with $(n=5)$ or 35 minutes $(n=5)$ after $100 \mathrm{mg}$ timolol.

Conclusion: Systemic administration of timolol does not affect the optic nerve oxygen tension despite its lowering effect on the intraocular pressure. Additionally, timolol does not affect the $\mathrm{ONPO}_{2}$ increasing effect of dorzolamide.

$\mathrm{T}$ opical $\beta$ blockers were one of the first effective pressure lowering drugs licensed for the treatment of primary open angle glaucoma. To this day they remain a first line drug for this condition. ${ }^{1}$ Topical carbonic anhydrase inhibitors (CAIs) are also widely used for lowering intraocular pressure in treating glaucoma, often used in combination with a $\beta$ blocker. $^{2}$

At least some forms of glaucoma are considered to have optic nerve ischaemia as an important part of their pathogenesis. ${ }^{3}{ }^{4}$ Accordingly, significant research efforts have been devoted to study the effects of $\beta$ blockers on retinal ${ }^{5-8}$ and optic nerve blood flow. ${ }^{10}$ Conflicting results have emerged from this; some of the reports have found that $\beta$ blockers decrease optic nerve head blood flow and others that they increase or do not affect blood flow.

We have previously shown that carbonic anhydrase inhibitors such as acetazolamide and dorzolamide elevate the oxygen tension of the optic nerve in pigs. ${ }^{11}$ In the present study, we investigated the effects of the $\beta$ blocker timolol on optic nerve oxygen tension. We also analysed the interactions between timolol and dorzolamide with regard to $\mathrm{ONPO}_{2}$.

\section{MATERIALS AND METHODS}

Domestic pigs (Danish Landrace) $(n=15), 28-30 \mathrm{~kg}$ in weight and brought up in a specific pathogen free environment, were used as experimental animals. Their treatment was supervised by a veterinarian nurse and followed the ARVO resolution for the use of animals in ophthalmic and vision research. Permission for the use of pigs in this study was granted by Dyreforsøgstilsynet (Danish Animal Experiments Inspectorate).

Dorzolamide $\mathrm{HCl}$ and timolol eye drops (Timacar) was obtained from Merck, Sharp \& Dohme (Glostrup, Denmark). Dorzolamide was dissolved as a $3 \%$ solution in $100 \mathrm{mM}$ citrate buffer, pH 5.6.

\section{Anaesthesia and animal preparation}

Anaesthesia was induced by an intramuscular injection of $15 \mathrm{mg}$ midazolam (Dumex-Alpharma) followed by $3 \mathrm{ml}$ of a mixture of tiletamin $25 \mathrm{mg} / \mathrm{ml}$ and zolazapam $25 \mathrm{mg} / \mathrm{ml}$ (Zoletil 50 vet, Boehringer Ingelheim), xylazin $13 \mathrm{mg} / \mathrm{ml}$ (Narcoxyl vet, Veterinaria AG), ketalar 15 mg/ml (Ketaminol, Veterinaria AG), and methadone 2.5/ml (Methadon DAK, Nycomed). After induction, the pigs were intubated, and artificially ventilated with air. Catheters were placed in the left femoral artery, left femoral vein, and in the left cranial superficial epigastrical vein. During the experiment, anaesthesia was maintained by infusion of pancuronium bromide $8 \mathrm{mg} /$ hour (Pavulon, Organon) and fentanyl $400 \mu \mathrm{g} / \mathrm{hour}$ (Fentanyl, Dumex-Alpharma) in one vein and pentobarbital $300 \mathrm{mg} /$ hour (mebumal, Den Kongelige Veterinær-og Landbohøjskoles Apotek, Denmark) in the other vein.

Heart rate (HR) and mean arterial blood pressure (MAP) was monitored throughout the experiments.

The pig was placed in a sling and the head additionally secured stereotactically. A speculum was placed between the eyelids of the left eye. The pupil of this eye was dilated with $1 \%$ atropine eye drops (Atropin SAD, Sygehusapotekerne i DK), $\quad 0.4 \%$ oxybuprocaine (Oxybuprokain SAD, Sygehusapotekerne i DK), 1\% cyclopentolate (Cyclogyl, Alcon), and 2.5\% methaoxedrine (methaoxedrine SAD, Sygehusapotekerne i DK). Two 4-0 silk traction sutures were placed in the sclera to immobilise the eye. A sclerotomy was made $2.0 \mathrm{~mm}$ behind the limbus in the superior nasal quadrant and a plastic cannula (16 gauge) was placed in the sclerotomy. To avoid contamination of the electrode with blood products, it was advanced through the cannula.

\section{Oxygen tension measurements}

The oxygen tension over the optic nerve was measured with a polarographic oxygen electrode with an internal $\mathrm{Ag} / \mathrm{AgCl}$ reference electrode, embedded in a 20 gauge needle (model 768-20R, Diamond General Development Corporation, Ann Arbor, MI, USA). The electrode was calibrated and the optic nerve oxygen tension measument were performed as previously described. ${ }^{12}$ 


\section{Experimental protocol}

Frequent arterial blood samples were drawn from the catheter in the femoral artery, and analysed for oxygen and carbon dioxide tensions and pH, using an ABL 605 blood gas analyser (Radiometer, Copenhagen, Denmark). The respirator was adjusted in stroke volume and frequency to ensure normal blood $\mathrm{PO}_{2}(\mathrm{apH})(10-14 \mathrm{kPa}), \mathrm{PCO}_{2}\left(\mathrm{aPCO}_{2}\right)$ (5.5$7.5 \mathrm{kPa})$ and $\mathrm{pH}$ values $(\mathrm{apH})(7.38-7.42)$ according to the blood samples.

To test the oxygen electrode, the pig was initially given $100 \%$ oxygen in the inspiratory air for 10 minutes. After having obtained a stable oxygen tension recording, five pigs were given intravenous injections of $100 \mathrm{mg}$ timolol initially and $500 \mathrm{mg}$ dorzolamide 35 minutes later, five pigs were given intravenous injections of $500 \mathrm{mg}$ dorzolamide and $100 \mathrm{mg}$ timolol 35 minutes afterwards, and five pigs were given a combination of $500 \mathrm{mg}$ dorzolamide and $100 \mathrm{mg}$ timolol intravenously simultaneously. Arterial blood samples were drawn at following time points according to the different drug injections: -1 minute, 1 minute, 10 minutes, and 30 minutes.

The mean total duration of the experiments was 4 hours and 47 (SD 88) minutes $(n=15)$. The electrode recordings lasted 3 hours and 22 (SD 81) minutes. The oxygen electrode drift was less than $-0.1 \mathrm{kPa}$ per hour.

\section{Data processing}

$\mathrm{ONPO}_{2}, \mathrm{MAP}$, and HR values (averaged over 15 seconds in the Axoscope recording) for baseline and time points after injection of the study drugs were used for all the calculations.

The mean and standard deviation of $\mathrm{ONPO}_{2}, \mathrm{apH}, \mathrm{aPCO}_{2}$, $\mathrm{aPO}_{2}, \mathrm{MAP}$, and HR were calculated (table 1).
Differences in the parameters before and after drug injections in each pig were tested for significance using Student's paired two tailed $t$ test. Difference between groups was tested for significance using Student's unpaired two tailed $t$ test. A significance level of 0.05 was used.

All results (table 1) were presented as mean (SD) ( $\mathrm{n}=$ number of experiments).

Graphic presentations of the tracings were made in SigmaPlot 2001 for Windows (Version 6.00 SPSS Inc, Chicago, IL, USA).

\section{RESULTS}

Timolol injection had no effect on $\mathrm{ONPO}_{2}$ (fig lA). Baseline $\mathrm{ONPO}_{2}$ was $4.33(0.25) \mathrm{kPa}(\mathrm{n}=5$, table 1$)$. This decreased insignificantly by $0.11 \quad(0.16) \mathrm{kPa}$ after timolol injection $(\mathrm{n}=5, \mathrm{p}=0.194$, figs $\mathrm{lA}$ and 2$)$. Injection of dorzolamide increased $\mathrm{ONPO}_{2}$ significantly by $0.72(0.39) \mathrm{kPa} \quad(\mathrm{n}=4$, $\mathrm{p}=0.035$, figs $\mathrm{IB}$ and 2 ). One experiment with injection of dorzolamide was excluded because of movement of the pig head; however, the measurements during the following injection of timolol could be performed satisfactorily and was included. When timolol was given to the dorzolamide treated pigs, $\mathrm{ONPO}_{2}$ increased insignificantly by $0.19(0.30)$ $\mathrm{kPa}(\mathrm{n}=5, \mathrm{p}=0.303$, fig $1 \mathrm{~B})$. Dorzolamide and timolol given simultaneously elevated $\mathrm{ONPO}_{2}$ significantly by 0.83 (0.18) $\mathrm{kPa}(\mathrm{n}=5, \mathrm{p}<0.001$, figs $\mathrm{lC}$ and 2$)$ and a similar increase was seen when dorzolamide was given to the timolol treated animal $(0.86(0.34) \mathrm{kPa}(\mathrm{n}=5, \mathrm{p}<0.001$, figs $\mathrm{lA}$ and $2)$ ). There was no significant difference between the effects of injection of $500 \mathrm{mg}$ dorzolamide when it was given in control animals, in timolol treated animals, or simultaneously with timolol (fig 2).

\begin{tabular}{|c|c|c|c|c|c|}
\hline & $\begin{array}{l}100 \mathrm{mg} \\
\text { timolol iv } \\
\text { (alone) }\end{array}$ & $\begin{array}{l}500 \mathrm{mg} \\
\text { dorzolamide iv } \\
\text { (after timolol) }\end{array}$ & $\begin{array}{l}500 \mathrm{mg} \\
\text { dorzolamide iv } \\
\text { (alone) }\end{array}$ & $\begin{array}{l}100 \mathrm{mg} \\
\text { timolol iv (after } \\
\text { dorzolamide) }\end{array}$ & $\begin{array}{l}500 \mathrm{mg} \\
\text { dorzolamide }+100 \mathrm{mg} \\
\text { timolol iv }\end{array}$ \\
\hline $\begin{array}{l}\mathrm{ONPO}_{2} \\
\text { (baseline) } \\
\text { (kPa) }\end{array}$ & $4.33(0.25)$ & $4.23(0.19)$ & $2.96(0.62)$ & $4.00(0.90)$ & $3.24(1.06)$ \\
\hline $\begin{array}{l}\mathrm{ONPO}_{2} \\
(30 \mathrm{~min}) \\
(\mathrm{kPa})\end{array}$ & $4.22(0.19)$ & $5.09(0.48)^{*}$ & $3.69(0.88)^{*}$ & $4.19(1.11)^{*}$ & $4.08(0.92)^{*}$ \\
\hline $\begin{array}{l}\text { apH } \\
\text { (baseline) }\end{array}$ & $7.40(0.01)$ & $7.41(0.01)$ & $7.41(0.01)$ & $7.33(0.02)$ & $7.41(0.01)$ \\
\hline $\begin{array}{l}\mathrm{apH} \\
\text { (30 min) }\end{array}$ & $7.41(0.01)$ & $7.33(0.02)^{*}$ & $7.34(0.01)^{*}$ & $7.32(0.01)^{*}$ & $7.33(0.01)^{*}$ \\
\hline $\begin{array}{l}\mathrm{aPCO}_{2} \\
\text { (baseline) } \\
\text { (kPa) }\end{array}$ & $7.2(0.6)$ & $7.0(0.6)$ & $7.2(0.4)$ & $8.4(0.5)$ & $6.7(0.2)$ \\
\hline $\begin{array}{l}\mathrm{aPCO}_{2} \\
(30 \mathrm{~min}) \\
(\mathrm{kPa})\end{array}$ & $7.0(0.6)$ & $8.4(0.5)^{*}$ & $8.2(0.4)^{*}$ & $8.6(0.4)^{*}$ & $8.0(0.4)^{*}$ \\
\hline $\begin{array}{l}\mathrm{aPO}_{2} \\
\text { (baseline) } \\
\text { (kPa) }\end{array}$ & $10.6(1.0)$ & $10.1(0.8)$ & $11.9(1.5)$ & $10.9(2.1)$ & $11.1(2.4)$ \\
\hline $\begin{array}{l}\mathrm{aPO}_{2} \\
(30 \text { min) } \\
(\mathrm{kPa})\end{array}$ & $10.1(0.8)$ & $10.2(0.8)$ & $12.3(1.4)$ & $10.9(2.2)$ & $11.1(2.4)$ \\
\hline $\begin{array}{l}\text { MAP } \\
\text { (baseline) } \\
\text { (mm Hg) }\end{array}$ & 114 (16) & $108(11)$ & $99(20)$ & $84(27)$ & $99(20)$ \\
\hline $\begin{array}{l}\text { MAP } \\
\text { (30 min) } \\
(\mathrm{mm} \mathrm{Ha})\end{array}$ & $110(12)$ & 99 (16) & $89(23)^{*}$ & $77(26)^{*}$ & $87(20)^{*}$ \\
\hline $\begin{array}{l}\text { HR } \\
\text { (baseline) }\end{array}$ & $86(7)$ & $89(5)$ & $99(20)$ & $86(11)$ & $94(30)$ \\
\hline \multicolumn{2}{|c|}{$\mathrm{HR}(30 \mathrm{~min}) 89(5)$} & $85(8)^{*}$ & $89(23)$ & $89(11)$ & $87(21)$ \\
\hline
\end{tabular}



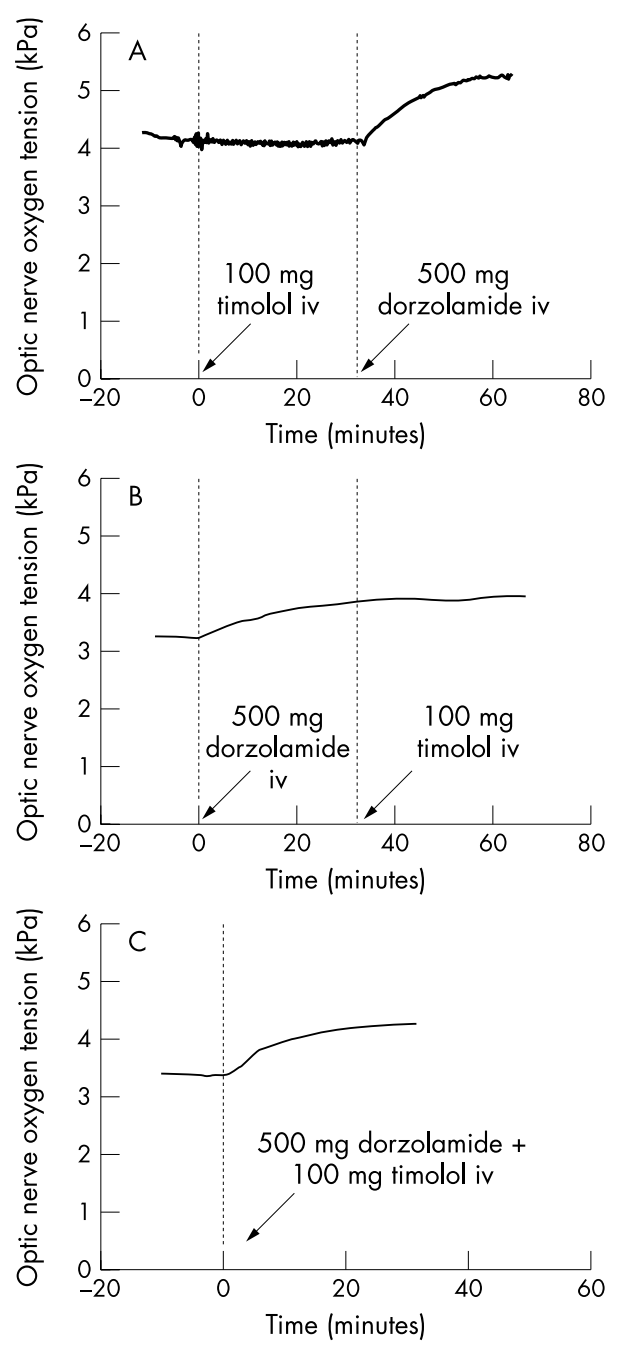

Figure 1 Optic nerve oxygen tension in $\mathrm{kPa}$ over time during different kinds of manipulations. (A) The effect of $100 \mathrm{mg}$ timolol injection at time 0 and a subsequent $500 \mathrm{mg}$ dorzolamide injection at 35 minutes. (B) The effect of $500 \mathrm{mg}$ dorzolamide injection at time 0 and a subsequent $100 \mathrm{mg}$ timolol injection at 35 minutes. (C) The effect of a combined injection of $100 \mathrm{mg}$ timolol and $500 \mathrm{mg}$ dorzolamide.

MAP and HR did not change after the injections of timolol, but decreased slightly in some of the groups when dorzolamide was injected (table 1).

Injection of timolol did not affect apH and $\mathrm{aPCO}_{2}$. However, an injection of dorzolamide created a metabolic acidosis, decreasing apH and increasing $\mathrm{aPCO}_{2}$ (table 1). Arterial $\mathrm{PO}_{2}$ did not change in any of the experiments.

\section{DISCUSSION}

There were two new findings in this study. Firstly, timolol injected intravenously had no significant effect on $\mathrm{ONPO}_{2}$. Secondly, the effect of dorzolamide on $\mathrm{ONPO}_{2}$ was not affected by timolol injection given neither before, in combination, nor after dorzolamide.

Carbonic anhydrase inhibitors may increase $\mathrm{ONPO}_{2}$ either through a lowering of the intraocular pressure (IOP), a vasodilatory effect on the vessels in the optic nerve, a decrease in the cellular oxygen metabolism, or a combination of these three factors. In this study we used two commonly used glaucoma drugs known to lower the IOP in glaucoma patients.

Pilot experiments have shown that intravenous injections of $100 \mathrm{mg}$ timolol as well as $500 \mathrm{mg}$ dorzolamide in healthy

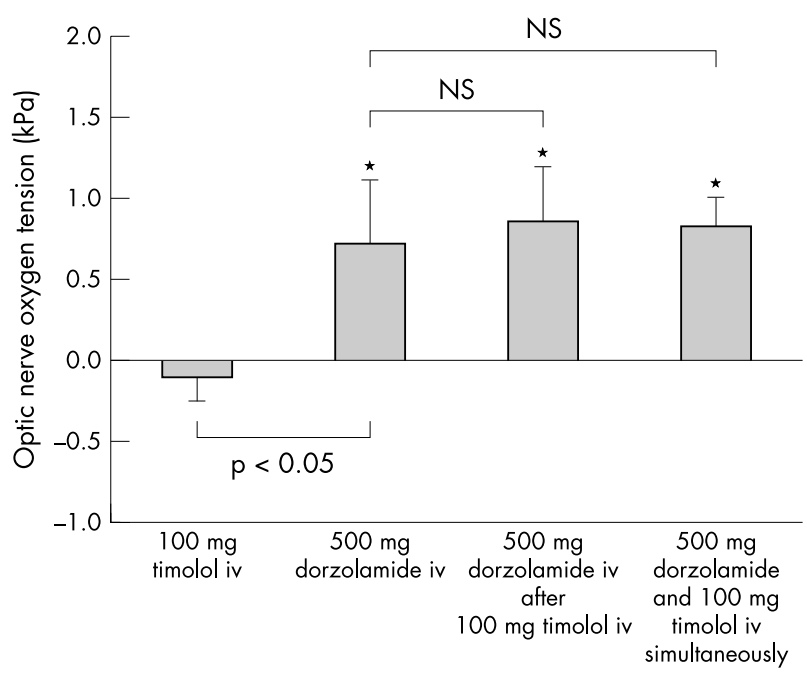

Figure 2 The changes in optic nerve oxygen tension induced by injections of timolol, dorzolamide, dorzolamide after timolol, and a combination of dorzolamide and timolol. *Indicates that the changes in $\mathrm{ONPO}_{2}$ from baseline are significant (Student's paired $t$ test). Changes in $\mathrm{ONPO}_{2}$ in the treatment groups were compared using Student's unpaired $t$ tests ( $p<0.05=$ significant difference).

pigs induce similar decreases in IOP of 5-6 mm Hg (data not shown). However, only dorzolamide was able to induce an increase in $\mathrm{ONPO}_{2}$, demonstrating that not all glaucoma drugs have an effect on the $\mathrm{ONPO}_{2}$ and indicating that decreasing IOP may not be an important factor for the dorzolamide induced increase in $\mathrm{ONPO}_{2}$. This is in line with previous experiments in pigs where the effect of dorzolamide on $\mathrm{ONPO}_{2}$ was shown to be similar in experiments with unclamped and clamped IOP. ${ }^{12}$ Unfortunately, a direct correlation between IOP and $\mathrm{ONPO}_{2}$ is difficult to show in these types of experiments. Because the oxygen measurements are invasive, the IOP measurements most likely are affected.

It has been shown that carbonic anhydrase inhibitors do not affect the metabolic rate of oxygen in brain tissue. ${ }^{13}$ Therefore, neither the oxygen metabolism nor the IOP lowering effect of CAI seem to have a role in the effect of CAI on $\mathrm{ONPO}_{2}$. Thus, we believe that the effect of dorzolamide on $\mathrm{ONPO}_{2}$ is caused by a vasodilatation of the optic nerve vasculature through carbon dioxide accumulation, metabolic acidosis, direct myogenic effect, or a combination of these three factors.

The effect of timolol and other $\beta$ blockers on ocular blood flow has been the subject of much interest. Many of these reports give conflicting results. This may to some degree be because of the use of different techniques, investigations in different vasculature, and also different study subjects. Additionally, most of the techniques measuring blood flow have difficulties in detecting small and moderate differences. The reports find either no effect or a small increase or decrease in ocular blood flow following timolol application. ${ }^{5-10}$ 14-16 In vitro experiments of the diameters of retinal arterioles also show small, but diverging effects. ${ }^{17} 18$

The only previous study of the effect of timolol on ocular oxygen tension is that of Pakalnis et al ${ }^{19}$ who studied anterior chamber oxygen tension in the cat and found this to be slightly decreased following timolol application.

MAP and HR decreased slightly in some of the groups where dorzolamide was injected. Dorzolamide is a vasodilatory drug that not only affects the cerebral vessels, but also may affect the systemic arterioles, thereby decreasing the systemic arterial blood pressure. Also the systemic acidosis 
that dorzolamide induces may lower MAP. $\beta$ Blockers block the adrenergic effect on the vessels and the heart, ${ }^{20}$ but timolol affected neither the heart rate nor the mean arterial blood pressure in the pigs in our experiments. However, it is known that $\beta$ blockers do not cause hypotension in healthy individuals with normal blood pressure. ${ }^{20}$ It has been shown that intravenous injections of $0.2 \mathrm{mg}$ timolol in healthy awake humans do not affect mean arterial pressure but do decrease heart rate. ${ }^{21}$ In humans the adrenergic positive chronotropic stimulation of the heart is lowered during sleep. ${ }^{22}$ We think this is why timolol does not affect the heart rate significantly in the anaesthetised pigs in our experiments.

These experiments were performed with intravenous injections of glaucoma drugs. Dorzolamide was used in a saturating dose of $500 \mathrm{mg}$ and timolol in a comparatively large systemic dose of $100 \mathrm{mg}$. This application is of course different from the typical topical application of these glaucoma drugs in the human. The aim was to discover the principal pharmacological effects of these drugs on the pig optic nerve and later to proceed to studies with smaller clinical doses in the human glaucoma patient. Having said that, it is of interest that the pharmacological effect of dorzolamide on the optic nerve was present with or without timolol application, before, after, or at the same time as the dorzolamide injection. This suggests that the combination of $\beta$ blockers and CAIs may be an effective method of affecting optic nerve oxygen tension and blood flow and, at the same time, lowering IOP.

\section{Authors' affiliations \\ J F Kiilgaard, D B Pedersen, M la Cour, P K Jensen, Department of Ophthalmology, Rigshospitalet, Copenhagen, Denmark \\ J F Kiilgaard, D B Pedersen, University of Copenhagen, Denmark T Eysteinsson, E Stefánsson, Department of Ophthalmology, University of Iceland, Reykjavik, Iceland \\ K Bang, Merck, Sharp \& Dohme, Glostrup, Denmark}

Correspondence to: Jens Folke Kiilgaard, MD PhD, Department of Ophthalmology, Rigshospitalet, Blegdamsvej 9, 2100 Copenhagen $\varnothing$, Denmark; jfk@dadlnet.dk

Accepted for publication 26 May 2003

\section{REFERENCES}

1 Coleman AL. Glaucoma. Lancet 1999;354:1803-10.
2 Kanski JJ. In: Kanski JJ, ed. Clinical ophthalmology. 4th ed. Oxford: Butterworth-Heinemann, 1999:183-261.

3 Jonas JB, Budde WM. Diagnosis and pathogenesis of glaucomatous optic neuropathy: morphological aspects. Prog Retin Eye Res 2000; 19:1-40.

4 Hamard P, Hamard H, Dufaux J. Blood flow rate in the microvasculature of the optic nerve head in primary open angle glaucoma. A new approach. Surv Ophthalmol 1994;38(Suppl):S87-S93.

5 Yoshida A, Ogasawara H, Fujio N, et al. Comparison of short- and long-term effects of betaxolol and timolol on human retinal circulation. Eye 1998; 12(Pt 5):848-53.

6 Grunwald JE. Effect of topical timolol on the human retinal circulation. Invest Ophthalmol Vis Sci 1986;27:1713-19.

7 Grunwald JE. Effect of two weeks of timolol maleate treatment on the normal retinal circulation. Invest Ophthalmol Vis Sci 1991;32:39-45.

8 Grunwald JE. Effect of timolol maleate on the retinal circulation of human eyes with ocular hypertension. Invest Ophthalmol Vis Sci 1990;31:521-6.

9 Yoshida A, Feke GT, Ogasawara H, et al. Effect of timolol on human retinal, choroidal and optic nerve head circulation. Ophthalmic Res 1991;23:162-70.

10 Arend O, Harris A, Arend S, et al. The acute effect of topical betaadrenoreceptor blocking agents on retinal and optic nerve head circulation. Acta Ophthalmol Scand 1998;76:43-9.

11 Stefánsson E, Jensen PK, Eysteinsson T, et al. Optic nerve oxygen tension in pigs and the effect of carbonic anhydrase inhibitors. Invest Ophthalmol Vis Sci 1999;40:2756-61.

12 la Cour M, Kiilgaard JF, Eysteinsson T, et al. Optic nerve oxygen tension: effects of intraocular pressure and dorzolamide. $\mathrm{Br} J$ Ophthalmol 2000:84:1045-9.

13 Vorstrup S, Henriksen L, Paulson OB. Effect of acetazolamide on cerebral blood flow and cerebral metabolic rate for oxygen. J Clin Invest 1984;74:1634-9.

14 Carenini AB, Sibour G, Boles CB. Differences in the longterm effect of timolol and betaxolol on the pulsatile ocular blood flow. Surv Ophthalmol 1994;38(Suppl):S1 18-S124.

15 Evans DW, Harris A, Cantor LB. Primary open-angle glaucoma patients characterized by ocular vasospasm demonstrate a different ocular vascular response to timolol versus betaxolol. J Ocul Pharmacol Ther 1999: 15:479-87.

16 Harris A, Spaeth GL, Sergott RC, et al. Retrobulbar arterial hemodynamic effects of betaxolol and timolol in normal-tension glaucoma. Am J Ophthalmol 1995; 120:168-75.

17 Yu DY, Su EN, Cringle SJ, et al. Effect of betaxolol, timolol and nimodipine on human and pig retinal arterioles. Exp Eye Res 1998;67:73-81.

18 Hoste AM. In vitro studies of the effects of beta-adrenergic drugs on retina and posterior ciliary microarteries. Surv Ophthalmol 1999:43(Suppl 1):S183-S190.

19 Pakalnis VA, Rustgi AK, Stefánsson E, et al. The effect of timolol on anteriorchamber oxygenation. Ann Ophthalmol 1987;19:298-300.

20 Hoffman BB, In: Katzung BG, ed. Basic and clinical pharmacology. 5th ed. East Norwalk, CT: Appleton \& Lange, 1992:124-38

21 Korte JM, Kaila T, Saari KM. Systemic bioavailability and cardiopulmonary effects of $0.5 \%$ timolol eyedrops. Graefes Arch Clin Exp Ophthalmol 2002;240:430-5.

22 Trinder J, Kleiman J, Carrington $M$, et al. Autonomic activity during human sleep as a function of time and sleep stage. J Sleep Res $2001 ; 10: 253-64$. 